\title{
Laurence Housman's Letters to \\ George Galloway, 1903-1905
}

When Laurence Housman's volume of poems, Green Arras, was published in 1896, the same year that A Shropshire Lad by A. E. Housman appeared, "the English public, who knew Laurence better than Alfred, received the book with much greater praise than they gave Shropshire Lad." Nowadays it's even difficult to locate a copy of Green Arras to read and compare; yet in his time Laurence Housman was a prolific writer, an internationally-known novelist_and a successful playwright, rivalling his now-more-famous brother who was the author of only two volumes of lyrics remarkable for economy of words and simplicity.

The University of Iowa Library has recently acquired 83 letters from Laurence Housman to George Galloway, a midwestern youth who lived with his mother in Eau Claire, Wisconsin. ${ }^{2}$ I spent a pleasant summer reading the sometimes sprawled, scrawled and illegible handwriting of a man not quite half-way through his life and not yet at the peak of his career as a playwright. He was nearing 40 , and George couldn't have been more than 23 , but the honest criticism and exchange of opinions and ideas on numerous subjects-war, pollution and even women's liberation-make me believe that perhaps the work of Laurence Housman deserves to be rediscovered or disentombed.

Of himself, Laurence Housman has written that "The man who

1 Maude M. Hawkins, A. E. Housman: Man Behind a Mask (Chicago, 1958), p. 228.

2 The other side of this correspondence is represented by 58 letters from George Galloway to Laurence Housman with four letters from Fannie Galloway. Additionally, the Library at present owns more than 60 of Laurence Housman's letters to other correspondents, spanning the years 1890-1941. Among these correspondents are Harley Granville-Barker, Philip Henderson, H. C. Morillier and Harry Quilter. Two drafts of The Pied Piper of Hamelin and miscellaneous items in prose and verse are also among the Library's Housman manuscripts. 
bears my name, and who claims to be me, was born on July 18 , 1865 , the sixth in a family of seven. He was an ugly child, and remained ugly till his eightecnth year, when his looks gradually improved. He was also, in those early years, rather a weakling, bad at athletics, not fond of exercise, a continuous but slow reader, lazy at work which did not interest him-and at his school, did little; in solitary leisure a persistent day-dreamer; in company a victim of 'the inferiority complex,' from which he has never got free, and is still in consequence, defensively pugnacious." ${ }^{3}$

Most of Laurence Housman's principal works appeared after 1903, the year of the beginning of this correspondence. Why then is young George Galloway not even mentioned or referred to in Housman's autobiography, The Unexpected Years (1936)? Curious, for, like a typical character in an A. E. Housman poem, George was a doomed youth acting out the tragedy of his brief life in a context of agricultural activity. Who can say why he is omitted? In any event, Laurence Housman reveals in these letters a warm friendship for his young and distant correspondent. Because of this warmth of fecling, these letters make for good reading and may be important when scholars choose to do future research on "Laurence Housman's brother" or, hopefully, on Laurence Housman himself.

For a Housman, Laurence was not unusual in his combination of abilities, as he came from a family which was remarkable for versatility and a fair distribution of talent, reason enough for Laurence to suffer from an inferiority complex. But his grandfather has written that Laurence, of all the Housmans, was the most versatile. ${ }^{4}$ And, indeed, he distinguished himself as a dramatist, poet, novelist, journalist, essayist, illustrator and artist. "Inspired by the renaissance of book decoration begun by the leaders of the Pre-Raphaelite brotherhood, Housman came under the influence of his contemporaries Crane, Morris and Burne-Jones who were so closely allied to the Arts and Crafts movement of the period. Their aim was to produce designs and illustrations which should not only be beautiful in themselves, but in relation to the book as a whole." The House of Joy, a collection of eight short stories first published in 1895, reveals some of Laurence Housman's fine drawing and technical ability. Books of sketches, essays or poems followed nearly every year from this prolific and studious man.

In an undated typed letter, rare among his usually-handwritten correspondence, Laurence Housman said that his acquaintance began

3 Stanley J. Kunitz, ed., Authors Today and Yesterday (New York, 1933), p. 328.

4 Hawkins, A. E. Housman: Man Behind a Mask, p. 19.

5 Publishers' Weekly (October 4, 1947), p. 1827. 
with George being a bit huffed at Laurence's suspicions that Galloway might be an interviewer in disguise. Apparently Housman was visited once in England by this young man, who was in his very early twenties at the time. In his first letter to George, dated January 3, 1903, from the address he shared with his sister Clemence, Laurence tells George that he is glad to get his letter since "he has the memory of his face before him and very pleasantly." The correspondence, which extends over a period of thirty months, from 1903 through July, 1905, reveals a close and personal friendship between the 38-year-old artist-writer and the young Christian Scientist who was dying from tuberculosis. Laurence says, "It is right and natural that generous minds while in the twenties should think the books which try to reform the world's wrong the greatest of all." 8 George Galloway may have believed that Laurence's work was of this nature.

On the subject of letters, Laurence was an expert. He had ventured away from short stories for a brief time in 1900 to potboil anonymously An Englishwoman's Love-Letters. Of that he has said, "I have always been a writer of letters, and of long ones; so, when I first thought of writing a book in the form of letters, I knew that I could do it quickly and easily."7 Laurence's letters to George were long and frequent, for to him the longest letter was still shorter than a short chapter of a novel, and a man who couldn't afford time to read that much had not time to be human.

In his first letter, Laurence Housman refers to his book A Modern Antaeus as evidence of how susceptible he is to the charm of the enthusiastic young. "Any friendly demonstration from that direction gladdens me."8 In another letter he says that happy minds have a great attraction for him; and if they are still very young and crude he likes them all the better and feels all the more complimented when they care to talk to him. ${ }^{9}$ He regretted that A Modern Antaeus (1901), which had been rushed into print to follow up the success of his one and only "best seller," and was a very much better piece of work, did not have the success which it deserved. "While An Englishuroman's Love-Letters is remembered against me, A Modern Antaeus is forgotten." 10 And, sure enough, I was able to locate the former in my local public library but not the latter.

6 Letter from Laurence Housman to George Galloway, June 29, 1904. Future footnote citations to the letters will identify Housman and Galloway only by initials.

7 Laurence Housman, The Unexpected Years (New York, 1936), p. 138.

$8 \mathrm{LH}$ to GG, January 3, 1903.

9 LH to GG, December 23, 1903.

10 Housman, The Unexpected Years, p. 135. 
The religious beliefs and social attitudes of Laurence Housman and his brother Alfred (A. E.) were so different that there was no hope of their even discussing them, and Laurence had learned long ago to veer off any such danger. But he didn't veer away from any subject when writing to George Galloway. It was as though he could bare his soul and let all his opinions and ideas flow forth in correspondence to his young friend in an unabashed and brotherly intimacy. In one letter he told George of Chim, a hermit whom he described as his chief care in life next to his sister Clemence. "When he laughs a sort of ripple-and-jig runs over him and sets his head nodding." I1 In that same letter he also asked George not to misspell "Houseman," as though he forgot to wipe his boots on coming into the house. Nevertheless, his sympathy was genuine. At some time in the correspondence he was made aware of George's consuming illness, and he assured the boy that he wrote to him not through pity but through affection. A little better than midway through the letter, he wrote, "If I loved all the world as I do you, I shouldn't write books to it: I should only write letters to it, and that would be only a clumsy stage on the way to entire telepathy."12

Two subjects appear to be Housman's favorites-love and religion. In his fourth letter to George, dated May 2, 1903, he mentions having sent George a book. "It is the sincerest thing I have written, caught by the drama of a soul struggling in the contrary toils of love and religion-death brought them into harmony." Laurence continued his advice: "I believe absolutely in love being the central motive force of the universe. Be. Don't do! Continue to be, and let me have nonobituary notices of you from time to time."13 One can only surmise that Laurence Housman's poem on friendship which appeared in the Fortnightly Review (January, 1904) might somehow have been linked with George Galloway, or, if not that one, then perhaps the poem on two "Comrades" in Harper's magazine (Spring, 1905) or a short story, proofs of which he sent to George, titled "The Cloak of Friendship." His theory of love was that love (like prayer) should make us better able to face life; Laurence may have been encouraging George to recover from his debilitating illness. "Learn to consider yourself robust, my Christian scientist."14

On the other subject, religion, Laurence instructed George to read his Bible-a most priceless trainer of heart, brain and style. In their

11 LHto CG, January 11, 1904.

12 L.H to GG, September 16, 1904.

$13 \mathrm{LH}$ to GG, October 2, 1903.

14 LH to GG, October 17, 1904. 
theological exchange George said that man had it in his soul to become as powerful as God is, and Laurence agreed, meaning simply that man has the power to rise to the height of his conceptions. Laurence Housman's whole theology was bound in two statements: 1) God is love, and 2) the Kingdom of Heaven is within you. ${ }^{15}$ How different was his attitude now from that expressed in his early book, Gods and Their Makers (1897) which he had written when he was aggressively atheistic. That book ends with the heroes sailing away from the island of the gods. Of that he has written elsewhere, "I was just then going through a healthy reaction from the orthodoxy of my youth; religion had become for me not so much a possession as an obsession, which I was trying to throw off, and this iconoclastic tale of an imaginary tribe was the result. ... That book was the symptom of something that has persisted till now; I have never been able to lose my interest in man's false gods, and in his age-long quest for one which, though unprovable, may yet be true. . . I I still think that if the human race, or even one nation, could only get right about its God the rest would follow."16

Laurence shared his likes and dislikes of writers and literature with his young friend, who once asked him whether he should stand on his legs as an embattled farmer or fire journalistic shots around the world. Although little biographical information is available, the letters revcal that George Galloway was a journalist for a short while. He was also an aspiring writer who sent his own short stories and books to the older, more successful man, who urged him not to consider himself wasted on backwoods and cornfields. Laurence, in turn, voiced his opinions on certain American writers. Laurence wrote to George of Frank Norris as one who, in the early 1900's, interested him in American life more than any other writer and as one who belonged to "that set which has the breath of life breathed in them up one nostril by God and up the other by the devil."17 He praised William Dean Howells as very nice and easy to get on with and called him "The American Lion." When referring to Rebecca of Sunnybrook Farm, which George had sent him, he admitted that he didn't like the second half and thought the author ought to look at Louisa May Alcott's work. He also noted that his character "Antaeus" had read Thoreau when he was seventeen.

That he was a lover of William Blake we know from his study, The Writings of William Blake (1893), and from his illustrations of the

15 LH to GG, May 18, 1904.

16 Housman, The Unexpected Years, p. 99.

17 LH to GG, February 23, 1903. 
Romantic poet. After receipt of a gift woven by George himself, Laurence noted that the basket deserved to be memorialized in the words of an unpublished poem of Blake's about fair maids at play "who lightly trip on beauty's toe, or sit on beauty's bum." 18 Housman had an extraordinary humor and frankness. He expressed dislike for Shelley's longer pieces and thought much of what he wrote was "slop." He also thought Swinburne was not too grand. He reckoned Keats' odes the top note of poctry. He must also have favored Christina Rossetti, whose Goblin Market (1893 edition) contains some of Laurence's best drawing, as does Meredith's Jump to Glory Jane (1892). Laurence sent The Return of the Native to George (who liked the novel much) and told him to read Far From the Madding Crowd, which he believed really not so pessimistic since Hardy thought it better "to be good and unhappy than bad and happy."19 When reading Jude the Obscure Laurence noted Hardy's same symbolic use of a trapped rabbit that he himself had made use of in one of his own novels. "So I will have to put in some footnote or preface or critics will say I cribbed."-0 In another letter, dated August 3, 1903, he discussed how Hardy brings out the irony of things in his novels-"well, a man might with equal right bring out the inconclusiveness, the loose-jointedness of life-if he sees it that way." He advised George to read'Joscph Conrad, lavishing special praise on Lord Jim, "a wondrous book." Of William Butler Yeats he wrote, "Yeats seems to me too often to try and find a disembodiment for beauty, and that is the reverse of what the poet's mission ought to be ..."21 $\mathrm{He}$ explained to George that Yeats hated H. G. Wells and said of him, "He has a mind like a sewing machine."22

Of how he got into the whole business Laurence has written, "My failure, during the first five or six years of my art training, to get set in the right direction, and the disappointment which it caused me, drove me the more persistently into writing as an alternative. But though I wrote much and constantly, I had no confidence that I could become an author. And it was that lack of confidence, I suppose, which made me keep the first book I ever wrote lying idle for five years, before trying it on a publisher, and it took three more years to find one." ${ }^{23}$ He believed it would be admirable discipline for one's literary soul to destroy, without committing it to memory, one poem a day

18 LH to GG, March 4, 1905.

19 LH to GG, August 21, 1904.

20 LH to GG, March 13, 1904.

21 L.H to GG, March 7, 1904.

22 L.H to GG, July 14, 1905.

23 Housman, The Unexpected Years, p. 99. 
while one was at the poetic spawning stage, so as to remain in the right detached state for fresh influence. He recommended Montaigne on that subject. However, "I'm a youngster myself still in that matter, and write more for tears than for laughter. ..."24

Of literary grist, Laurence wrote, "A man paying the penalty, without whining, for his good or his bad deeds, is always a good subject." $25 \mathrm{He}$ also felt "the revengeful God makes mighty fine literature, and that is all you ought to care about until you "find religion." "26 For Laurence, the ideal novel should combine virtues of trick, stratagem and surprise. The novel was then satisfying if it gave him real people, if it succeeded in localizing and making the reader feel as though he were there. "I think I like the novel as a means for giving a less violent and condensed focus of life. . . ."27 More advice to George in a letter dated April 3, 1903, was to make his romantic people do real things. Of his own writing habits, Laurence informed George that when he was depressed he would switch from the writing of Sabrina to a fairy tale or poetry, then comic verse, then to Gcorge. "Depression does at all events mean a wasted day of one's existence." 28

While he was writing Sabrina Wurham (1904), Housman confided in George about his past endeavors and his current projects as though he were keeping a sort of work schedule or journal. He was outspoken on many subjects, and his intimate correspondence with George reveals his opinions and attitudes. He was noted as a writer of the "cleanest" plays in England and at the same time as the most frequently censored of English dramatists. No fewer than 32 of his dramas, long and short, had been banned by the Lord Chamberlain because they dealt either too intimately with English royalty or too frankly with religion. In a letter dated December 15, 1903 he wrote that he thought many people hankered for a battle between Russia and Japan -just for the excitement of its happening and of reading about it. Referring to the war he added, "America will stand out and get the benefits. England will go in and get the knocks." 29

In addition to opinions on politics and war he set forth ideas on pollution and women's liberation which are still relevant in 20thcentury America. He expressed his hope that George's move to Colorado would do the boy some good (George had been living in New York for a short period), and in a letter of October 11, 1904, he wrote,

24 LH to GG, May 2, 1903.

25 LH to GG, February 23, 1903.

$26 \mathrm{LH}$ to GG, May 2, 1903.

27 LH to GG, June 23, 1903.

28 LH to GG, February 9, 1904.

29 Ibid. 
"Be of good cheer, beloved, you will be breathing clean air and that in itself is good work in these days when the belching breath of factories is allowed to foul so much of Heaven's face because of our grumbling wants, and puff puff notions of progress."

Women's liberation won his favor, much to his brother Alfred's repugnance. On January 27, 1905, Housman wrote to George, "No social code can ever secure true equality that does not begin by giving true equality to the sexes." He followed these words with action, for he had a greater social conscience than his brother and an even more open mind, as well as an understanding heart. During the period of the "Votes for Women" controversy, A. E. had been angered and embarrassed when his brother supported Clemence in her fight for women's rights. The two of them had spoken for suffrage in both London and Cambridge, and their pictures appeared in London papers as leaders in the movement. In 1911 A. E. wrote to Grant Richards: "There is a lovely portrait of my disreputable relatives in yesterday's Standard." 30 The only women A. E. ever liked were women who were of the hearth and home, wrapped in domestic affairs and looking well to the ways of their households. Model menu. makers, perfect hostesses, serene helmsmen of their private vessels, such women commanded A. E. Housman's respect and, once in a blue moon, his liking. Clemence would have lived up to his severe qualifications perfectly if she had not identified herself heart and soul with the suffrage movement and if she had not supported Laurence in his schemes for the social salvation of the world. The two brothers were indeed at opposite poles.

Laurence Housman's correspondence with his young American friend was brought to a close by George Galloway's death in the summer of 1905. Among their letters now preserved in The University of Iowa Libraries is a copy of a poem by A. E. Housman which ("since you are a lover of the Shropshire Lad") Laurence sent to George in 1904-a few months before the young man's death and 18 years before its eventual publication in A. E. Housman's Last Poems. Typically, almost presciently for young George, this poem concludes with the dolorous lines:

And I shall die tomorrow

But you shall die today.

30 Hawkins, A. E. Housman: Man Behind a Mask, p. 225. 


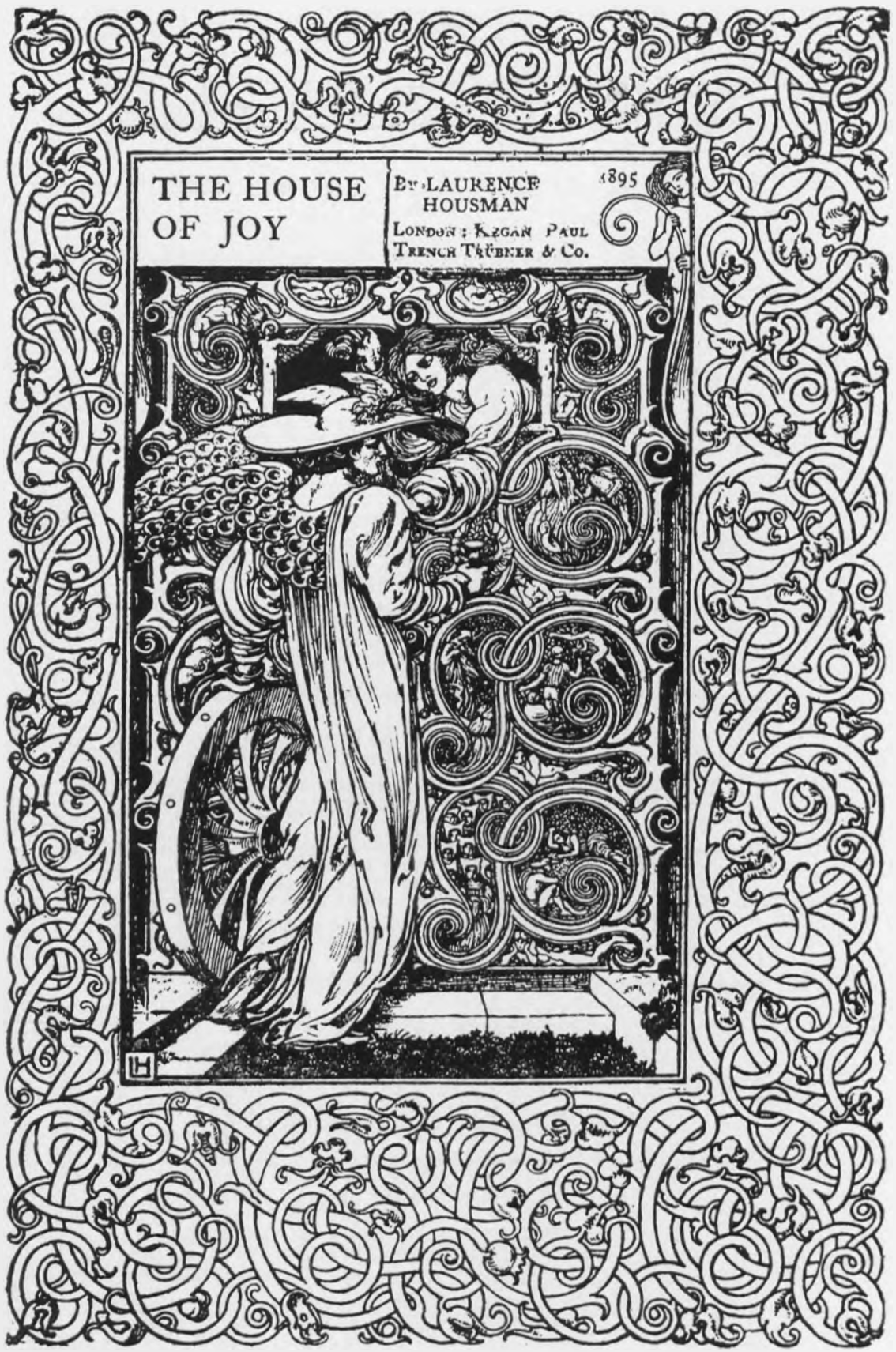

()rnate title page designed by Lamrence Honsman for his book The Housc of Joy. published in 1895. Reproduced by permission of Routledge \& Kogan l'anl I.tel. 